\title{
Effect of Dual Inoculation of Bacillus subtilis and Bradyrhizobium japonicum on Growth Parameters of Soybean (Glycine max L.)
}

\author{
V.V. Petkar*, T.T. Deshmukh and A.N. Jadhav \\ Department of Plant Pathology and Agricultural Microbiology, RCSM College of Agriculture \\ Kolhapur (M.S.), India \\ *Corresponding author
}

\section{A B S T R A C T}

\begin{tabular}{|l|}
\hline Ke y w or d s \\
$\begin{array}{l}\text { Soybean, Bacillus } \\
\text { subtilis, Bradyrhizobium } \\
\text { japonicum and growth }\end{array}$ \\
\hline Article Info \\
\hline $\begin{array}{l}\text { Accepted: } \\
\text { 06 September } 2018 \\
\text { Available Online: } \\
\text { 10 October } 2018\end{array}$ \\
\hline
\end{tabular}

\section{Introduction}

Soybean (Glycine max L.) is one of the most important pulse crops in world. The cultivated soybean originated in china during $2800 \mathrm{BC}$. It was introduced in India in 1950's (Caldwell, 1970; kumar et al., 2011). In India, the area and productivity have been rapidly increasing over the recent years. It plays major role in oil economy of India. It supplies $43.3 \%$ protein and $19.5 \%$ oil. The production of soybean in India is dominated by Maharashtra and Madhya Pradesh, which contribute $84.08 \%$ of the total production. Currently, India ranks fourth in production of soybean in the world (Anonymous, 2016).
Field experiment was conducted during Kharif, 2017 at Farm of Agronomy, RCSM College of Agriculture, Kolhapur. To study the effect of dual inoculation of Bacillus subtilis and Bradyrhizobium japonicum along with graded levels of chemical fertilizers on plant growth parameters of soybean (Glycine max L.) The dual inoculation of Bacillus subilis and Bradyrhizobium japonicum along with $75 \%$ nitrogen and phosphorus superior over rest of the treatment in ameliorating growth parameters. Which recorded highest germination $(86.94 \%)$, height of plant at $50 \%$ flowering $(58.32 \mathrm{~cm})$, number of main branches at $50 \%$ flowering (7.66), dry plant weight at $50 \%$ flowering $\left(28.39\right.$ g plant $\left.^{-1}\right)$, number of root nodules plant ${ }^{-1}$ at $50 \%$ flowering (120.37), dry weight of root nodules $\left(1.60\right.$ plant $\left.^{-1}\right)$ and dry matter yield at harvesting $\left(30.90 \mathrm{q} \mathrm{ha}^{-1}\right)$. However, above treatment did not differ significantly from those recorded with $B$. japonicum and $B$. subtilis along with $100 \%$ recommended dose of fertilizers and un-inoculated control. 
yield (Bai et al., 2003). Co-inoculation studies with Bacillus subtilis and Rhizobium/ Bradyrhizobium spp. have been shown to increase root and shoot biomass, nodule dry matter, nitrogenase activity, $\mathrm{N}_{2}$-fixation, and grain yield in legumes (Elkoca et al., 2008).

\section{Materials and Methods}

The experiment was carried out during Kharife, 2017 at Agronomy Farm, RCSM College of Agriculture, Kolhapur in RBD with 12 treatments and 3 replication. The treatment consist of $\mathrm{T}_{1}=B$. japonicum alone, $\mathrm{T}_{2}=B$. subtilis alone, $\mathrm{T}_{3}=B$. japonicum $+50 \% \mathrm{~N}$ and $\mathrm{RD}$ of $\mathrm{P}, \mathrm{T}_{4}=$ B. japonicum $+75 \% \mathrm{~N}$ and $\mathrm{RD}$ of $\mathrm{P}, \mathrm{T}_{5}=B$. japonicum $+\mathrm{RDF}, \mathrm{T}_{6}=B$. subtilis $+50 \% \mathrm{P}$ and $\mathrm{RD}$ of $\mathrm{N}, \mathrm{T}_{7}=B$. subtilis $+75 \% \mathrm{P}$ and $\mathrm{RD}$ of $\mathrm{N}, \mathrm{T}_{8}=$ B. subtilis + $\mathrm{RDF}, \mathrm{T}_{9}=$ B. japonicum + B. subtilis $+50 \%$ $\mathrm{N} \& \mathrm{P}, \mathrm{T}_{10}=$ B. japonicum + B. subtilis +75 $\% \mathrm{~N} \& \mathrm{P}, \mathrm{T}_{11}=$ B. japonicum + B. subtilis + $\mathrm{RDF}$ and $\mathrm{T}_{12}=$ Uninoculated control (RDF). Soybean variety named KDS-344 (Phule Agrani) was swon in net plot size $5.40 \mathrm{~m} \mathrm{x}$ $4.00 \mathrm{~m}$ with the row to row spacing $45 \mathrm{~cm} \times 5$ $\mathrm{cm}$ plant to plant spacing.

The recommended dose of fertilizer was applied 50:75:00 N, $\mathrm{P}_{2} \mathrm{O}_{5}, \mathrm{~K}_{2} \mathrm{O} \mathrm{kg} \mathrm{ha}{ }^{-1}$ with 25 Cartloads of FYM ha ${ }^{-1}$. All the intercultural operation was carried out as per need. The data recorded on various parameters were subjected to statistical analysis and F- test was applied as per method (Panse and Sukhatme 1985).

\section{Observation recorded}

\section{Plant growth parameters}

\section{Germination percentage}

The seed germination percentage was recorded 10 days after sowing. It was calculated by following formula:
Germination $(\%)=\frac{\text { Number of germinated seed } \times 100}{\text { Total number of seeds }}$

\section{Height of plant at $50 \%$ flowering}

Height of plant in a treatment was observed at $50 \%$ flowering stage of the crop, on randomly selected five plants per treatment.

Number of main branches at $50 \%$ flowering

Number of main branches plant ${ }^{-1}$ in a treatment was recorded at $50 \%$ flowering stage of the crop, on randomly selected five plants per treatment.

\section{Dry plant weight at $50 \%$ flowering (g plant ${ }^{-}$ 1)}

Five randomly selected plant samples from each treatment were uprooted as destructive samples at $50 \%$ flowering stage of the crop. The samples were oven dried at $70^{\circ} \mathrm{C}$ for 72 hrs. and average weight was taken as dry matter.

\section{Number of nodules per plant at $50 \%$ flowering}

Five randomly selected plants were carefully uprooted from each plot at $50 \%$ flowering stage for nodulation count.

The uprooted plants were washed under running tap water and finally cleaned with a soft camel hair brush to remove soil particles adhering to root surface. The nodules from the root system of each plant were separately collected and counted.

\section{Dry weight of nodules ( $\mathrm{g}$ plant $^{-1}$ )}

The nodules were air dried and then oven dried at $65^{\circ} \mathrm{C}$ for $72 \mathrm{hrs}$ and recorded their oven dry weights. 


\section{Dry matter yield $\left(\mathrm{ha}^{-1}\right)$}

Dry matter weight per plot was recorded as $\mathrm{kg}$ plot $^{-1}$ and was converted in to $\mathrm{q} \mathrm{ha}^{-1}$.

\section{Results and Discussion}

The data recorded in table 1 , all the treatments dual inoculation of Bradyrhizobium japonicum and Bacillus subtilis along with $75 \%$ of the recommended dose of nitrogen and phosphorus recorded highest germination per cent (86.94), height of plant at $50 \%$ flowering $(58.32 \mathrm{~cm})$, number of main branches at $50 \%$ flowering (7.66), dry plant weight $g$ plant $^{-1}$ at $50 \%$ flowering (28.39), number of root nodules plant ${ }^{-1}$ at $50 \%$ flowering (120. 37), dry weight of root nodules plant- ${ }^{1}(1.60)$ and dry matter yield q ha ${ }^{-1}$ at harvesting (30.90) at par with treatment $\mathrm{T}_{11}$ (B. japonicum $+B$. subtilis $+\mathrm{RDF}$ ) and $\mathrm{T}_{12}$ (Uninoculated control).

The lowest values were recorded in treatment $\mathrm{T}_{2}$ (B. subtilis alone) viz., germination $(65.30$ $\%)$, height of plant at $50 \%$ flowering (35.45 $\mathrm{cm}$ ), number of main branches at $50 \%$ flowering (2.03), dry plant weight at $50 \%$ flowering (10.27 $\left.\mathrm{g}_{\text {plant }}{ }^{-1}\right)$, number of root nodules plant ${ }^{-1}$ at $50 \%$ flowering (80.03), dry weight of root nodules $\left(0.73\right.$ plant $\left.^{-1}\right)$ and dry matter yield at harvesting $\left(15.18 \mathrm{q} \mathrm{ha}^{-1}\right)$.

Table.1 Dual effect of Bacillus subtilis and Bradyrhizobium japonicum on yield and yield attribute of soybean

\begin{tabular}{|c|c|c|c|c|c|c|c|c|}
\hline $\begin{array}{l}\text { Tr. } \\
\text { No }\end{array}$ & Treatment details & $\begin{array}{c}\text { Germin } \\
\text { ation } \\
(\%)\end{array}$ & $\begin{array}{c}\text { Height } \\
\text { of plant } \\
\text { at } 50 \% \\
\text { flowerin } \\
\mathrm{g}(\mathrm{cm})\end{array}$ & $\begin{array}{c}\text { No. of } \\
\text { main } \\
\text { branches } \\
\text { at } 50 \% \\
\text { flowering }\end{array}$ & $\begin{array}{c}\text { Dry plant } \\
\text { weight at } \\
50 \% \\
\text { flowering } \\
(\mathrm{g} \text { plant } \\
\end{array}$ & $\begin{array}{l}\text { No. of root } \\
\text { nodules } \\
\text { plant } t^{-1} \text { at } \\
50 \% \\
\text { flowering }\end{array}$ & $\begin{array}{c}\text { Dry } \\
\text { weight } \\
\text { of root } \\
\text { nodules } \\
\text { plant }^{-1}\end{array}$ & $\begin{array}{c}\text { Dry } \\
\text { matter } \\
\text { yield at } \\
\text { harvesti } \\
\text { ng } \\
\left(\mathrm{q} \mathbf{h a}^{-1}\right)\end{array}$ \\
\hline $\mathrm{T}_{1}$ & B. japonicum alone & 67.20 & 39.18 & 2.17 & 12.37 & 82.40 & 0.81 & 17.48 \\
\hline $\mathbf{T}_{2}$ & B. subtilis alone & 65.30 & 35.45 & 2.03 & 10.27 & 80.03 & 0.73 & 15.18 \\
\hline $\mathbf{T}_{3}$ & B. japonicum $+50 \% \mathrm{~N}$ and RDP & 73.35 & 45.73 & 4.13 & 18.34 & 90.35 & 0.92 & 21.26 \\
\hline$T_{4}$ & B. japonicum $+75 \% \mathrm{~N}$ and RDP & 78.84 & 52.41 & 6.33 & 24.35 & 115.6 & 1.35 & 27.28 \\
\hline$T_{5}$ & B. japonicum + RDF & 78.17 & 52.05 & 6.21 & 23.92 & 115.2 & 1.33 & 26.80 \\
\hline$T_{6}$ & B. subtilis $+50 \% \mathrm{P}$ and $\mathrm{RDN}$ & 69.15 & 42.19 & 3.51 & 13.97 & 84.34 & 0.76 & 20.23 \\
\hline$T_{7}$ & B. subtilis $+75 \% \mathrm{P}$ and RDN & 75.43 & 49.51 & 5.35 & 21.38 & 95.22 & 1.25 & 24.26 \\
\hline$T_{8}$ & B. subtilis + RDF & 75.13 & 49.31 & 5.22 & 20.90 & 94.89 & 1.24 & 23.73 \\
\hline $\mathbf{T}_{9}$ & B. japonicum + B. subtilis $+50 \% \mathrm{~N} \& \mathrm{P}$ & 71.28 & 42.86 & 3.10 & 16.26 & 86.40 & 0.83 & 20.50 \\
\hline $\mathrm{T}_{10}$ & B. japonicum + B. subtilis $+75 \% \mathrm{~N} \& \mathrm{P}$ & 86.94 & 58.32 & 7.66 & 28.39 & 120.37 & 1.60 & 30.90 \\
\hline$\overline{T_{11}}$ & B. japonicum + B. subtilis + RDF & 85.33 & 57.95 & 7.50 & 27.90 & 120.11 & 1.59 & 30.56 \\
\hline \multirow[t]{3}{*}{$T_{12}$} & Uninoculated control (RDF) & 84.18 & 56.97 & 7.15 & 27.21 & 119.55 & 1.57 & 30.21 \\
\hline & S.E \pm & 0.57 & 0.71 & 0.19 & 0.22 & 0.40 & 0.05 & 0.51 \\
\hline & C.D. at $5 \%$ & 1.67 & 2.09 & 0.57 & 0.64 & 1.17 & 0.15 & 1.48 \\
\hline
\end{tabular}

Note: $\mathrm{RDN}=$ Recommended dose of nitrogen, $\mathrm{RDP}=\mathrm{Recommended} \mathrm{dose}$ of phosphorus and RDF= Recommended dose of nitrogen and Phosphorus

The present results of increase in soybean germination due to inoculation of Bacillus subtilis and B. japonicum are similar to those Singh et al., (2011) stated that the bacterial species increased the germination due to dual inoculation, including B. subtilis. Tilak et al.,
(2006) reported that the dual inoculation of Bacillus subtilis and $B$. japonicum significantly increase plant height of soybean plant. Rajendran et al., (2008) reported growth promoting bacteria Bacillus shown to promote plant height. Bai et al., (2003) found 
that the combined application of a B. subtilis along with Bradyrhizobium in soybean significantly enhanced nodule number and nodule dry weight. Moreover, Sajid et al., (2010) also found significant effect on number of nodules per plant due to inoculation with Rhizobium. Abbasi et al., (2011) reported that seed inoculation with Rhizobium and PGPR had positive effect on number and weight of nodules. Whereas, at high Phosphorus conditions, coinoculation with Rhizobium spp. and B. subtilis significantly increased bean nodulation per plant (Roseline et al., 2007). Solomon et al., (2012) reported that the nodule number per plant in soybean were significantly influenced by Bradyrhizobium japonicum strains alone. Dashti et al., (1998) showed that the dual inoculation $B$. subtilis and $B$. japonicum significantly increased dry matter yields as compared with single inoculation of individual organisms in soybean. Patra et al., (2012) reported that response of soybean to inoculation with rhizobial strains increase plant dry matter of soybean over control due to inoculation with strain Bacillus spp.

To abridge, the results explicitly unveil that the inoculation of soybean seeds with Bacillus subtilis and Bradyrhizobium japonicum in conjunction with application of $75 \%$ of recommended dose of nitrogen and phosphorus had influential effect on grain yield of soybean.

\section{References}

Abbasi, M. K., Sharif, S., Kazmi, M., Sultan, T. and Aslam, M. 2011. Isolation of plant growth promoting rhizobacteria from wheat rhizosphere and their effect on improving growth, yield and nutrient uptake of plants. Plant Biosyst. 145 (1): 159168.
Anonymous, 2016. Handbook of statistics of Indian economy. (Reserve Bank of India 2015-16): 61-65.

Bai, Y., Zhou, X. and Mith, D. L. 2003. Enhanced soybean plant growth resulting from co-inoculation of Bacillus strain with Bradyrhizobium japonicum. Crop. Sci., 43: 1774-1781.

Caldwell, B. E. and Vest, G., 1970. Effects of Rhizobium japonicum strains on soybean yields. Crop Sci. 10: 19-21.

Dashti, N., Zhang, F., Hynes, R. and Smith, D. L. 1998. Plant growth promoting rhizobacteria accelerate nodulation and increase nitrogen fixation activity by field grown soybean [Glycine $\max (\mathrm{L}$.) Merr.] under short season conditions. Plant Soil. 200: 205-213.

Elkoca, E., Kantar, F. and Sahin, F. 2008. Influence of nitrogen fixing and phosphate solubilizing bacteria on nodulation, plant growth and yield of chickpea. J. Plant Nutr. 31: 157-171.

Kucey, R. M. N., Janzen, H. H. and Leggett, M. E. 1989. Microbially mediated increases in plant-available phosphorus, Adv. Agron. 42, 199-228.

Mathivanan, S., Chidambaram, A. L. A., Sundramoorthy, P., Baskaran, L. and Kalaikandhan, R. 2014. Effect of combined inoculations of plant growth promoting rhizobacteria (PGPR) on the growth and yield of groundnut (Arachis hypogaea L.). Int. J. Curr. Microbiol. App. Sci. 3 (8): 1010-1020.

Panse, V. S. and Sukhatme, P. V. 1985. Statistical method for agricultural workers, ICAR, New Delhi. 152-155.

Patra, R. K., Pant, L. M., and Pradhan, K. 2012.Response of Soybean to Inoculation with Rhizobial Strains: Effect on growth, yield, $\mathrm{N}$ uptake and soil N status. World J. Agric. Sci. 8 (1): 51-54.

Rajendran, G., Sing, F., Desai, A. J. and Archana, G. 2008. Enhanced growth 
and nodulation of pigeon pea by coinoculation of Bacillus strains with Rhizobium spp. Bioresour. Technol. 99: 4544-4550.

Sajid, M., Rab, F., Wahid, M., Shah, S. N., Jan, I., Hussain, S. A., Khan, M. A. and Iqbal, Z. 2010. Influence of rhizobium inoculation on growth and yield of groundnut cultivars. Sarhad J. Agric. 27 (4): 573-576.

Singh, J. S., Pandey, V. C. and Singh, D. P. 2011. Efficient Soil Microorganisms: A New Dimension for Sustainable Agriculture and Environmental Development. Agr. Ecosyst. Environ. 140 (3-4): 339-353.
Solomon, T., Pant, L. M. and Angaw, T. 2012. Effect of inoculation by Bradyrhizobium japonicum strains on nodulation, nitrogen fixation and yield of soybean (Glycine max. Merill) varieties on insitisols of Bako, Western Euthopia. Int. Scholorly Res. Network ISRN Agronomy. 261-475: 1-8.

Tilak, K. V. B. R., Ranganayaki, N. and Manoharachari, C. 2006. Synergistic effects of plant- growth promoting rhizobacteria and Rhizobium on nodulation and nitrogen fixation by pigeon pea (Cajanus cajan). Euro. J. Soil Sci. 57: 67-71.

\section{How to cite this article:}

Petkar, V.V., T.T. Deshmukh and Jadhav, A.N. 2018. Effect of Dual Inoculation of Bacillus subtilis and Bradyrhizobium japonicum on Growth Parameters of Soybean (Glycine max L.). Int.J.Curr.Microbiol.App.Sci. 7(10): 563-567 doi: https://doi.org/10.20546/ijcmas.2018.710.062 